\title{
ANALISIS NILAI TAMBAH AGROINDUSTRI KERIPIK SINGKONG (Studi Kasus Sentra Produksi Keripik Singkong Pedas di Kelurahan Setiamanah, Kecamatan Cimahi Tengah, Kota Cimahi)
}

\author{
Sulaiman $^{1}$, Ronnie Susman Natawidjaja ${ }^{2}$ \\ Program Studi Agribisnis, Fakultas Pertanian, Universitas Padjadjaran ${ }^{12}$ \\ sulaimanagan@gmail.com ${ }^{1}$, ronnienatawidjaja@unpad.ac.id ${ }^{2}$
}

\begin{abstract}
Small and Medium Enterprises in Indonesia opens opportunities for entrepreneurs to make cassava chips into their businesses and that can increase the added value of cassava. Cimahi city is one of the production centers of cassava chips, located in Kampung PojokKademangan, Setiamanah Village, Cimahi Tengah District, Cimahi City. The purpose of this research is to know the performance of agro-processing industry of cassava chips, business value and added value obtained from processing of cassava into cassava chips. This research uses qualitative design with case study technique. Data analysis contains business value analysis, value added analysis with Hayami method and descriptive with quantitative and qualitative data. The results shows that the processing of cassava chips still use the equipment is relatively simple and the average is a small industry. Marketing of cassava chips is done by entrepreneurs that directly selling cassava chips to consumers, besides through wholesalers and then to retailers then to consumers. The result of business value analysis shows that the average cost incurred by business of cassava chips at Production Center of Cassava Chips of Cassava Cimahi amounted to Rp4.598.410,53 with average received revenue of $R p 5.955 .600,00$ and average income / profit accepted entrepreneurs cassava chips is Rp1.321.284,17 in one production. The result of business efficiency analysis shows that the average $R / C$ ratio is 1.30. Which means cassava chips agro-industry is efficient or feasible because it already exceeds the number 1.00. The average value added is received on the business of cassava chips amounting to Rp5.232,18 per kilogram with a ratio of added value to the average output value of 23,76\% per production process. This added value added ratio is included in the medium category because it is between 15-40\% based on Hubeis Statement.
\end{abstract}

Keyword: Cassava, Value Added, business value, Cassava Chips

\begin{abstract}
ABSTRAK
Salah satu upaya diversifikasi hasil tanaman ubi kayu adalah pembuatan ubi kayu menjadi keripik singkong. Banyaknya Usaha Mikro, Kecil dan Menengah di Indonesia membuka peluang bagi para pengusaha untuk mengusahakan keripik singkong menjadi usaha yang dapat meningkatkan nilai tambah ubi kayu. Kota Cimahi merupakan salah satu daerah sentra produksi keripik singkong, yang bertempat di Kampung Pojok-Kademangan, Kelurahan Setiamanah, Kecamatan Cimahi Tengah, Kota Cimahi. Tujuan dari penelitian ini adalah untuk mengetahui keragaan agroindustri pengolahan keripik singkong, nilai usaha dan nilai tambah yang diperoleh dari pengolahan ubikayu menjadi keripik singkong. Penelitian ini menggunakan desain kualitatif dengan teknik studi kasus. Analisis data terdiri dari analisis nilai usaha, analisis nilai tambah dengan metode Hayami dan deskriptif dengan data kuantitatif dan kualitatif. Hasil penelitian menunjukkan bahwa proses pengolahan keripik singkong masih menggunakan peralatan yang relatif sederhana dan rata-rata merupakan industri kecil. Pemasaran keripik singkong dilakukan oleh pengusaha yaitu pengusaha langsung menjual keripik singkong kepada konsumen, selain itu melalui
\end{abstract}


pedagang grosir lalu ke pedagang-pedagang pengecer kemudian ke konsumen. Hasil analisis nilai usaha menunjukkan bahwa rata-rata biaya yang dikeluarkan oleh usaha keripik singkong di Sentra Produksi Keripik Singkong Pedas Cimahi sebesar Rp4.598.410,53 dengan rata-rata penerimaan yang diterima sebesar Rp5.955.600,00 dan rata-rata pendapatan/keuntungan yang diterima pengusaha keripik singkong adalah sebesar Rp1.393.585,30 dalam satu kali produksi. Hasil analisis efisiensi usaha menunjukkan bahwa rata-rata $R / C$ rasio yang didapatkan adalah 1,30 . Yang artinya agroindustri keripik singkong sudah efisien atau layak karena sudah melebihi angka 1,00. Rata-rata nilai tambah diterima pada usaha keripik singkong sebesar Rp5.232,18 per kilogram dengan rasio nilai tambah terhadap nilai output rata-rata sebesar $23,76 \%$ per proses produksi. Rasio nilai tambah ini termasuk dalam nilai tambah tersebut termasuk dalam kategori sedang karena berada diantara 15-40\% berdasarkan pernyataan Hubeis.

Kata kunci: Ubi Kayu, Nilai Tambah, Nilai Usaha, Keripik Singkong

\section{PENDAHULUAN}

Sektor pertanian mampu memberikan kontribusi yang sangat besar dalam pembangunan, seiring dengan proses pembangunan dan semakin meningkatnya sektor-sektor lain (Ismini, 2010). Salah satu komoditas tanaman pangan yang besar peranan selain padi dan jagung di Indonesia adalah ubi kayu. Ubi kayu (Manihot esculenta) merupakan salah satu tanaman pangan yang memiliki banyak kelebihan (Hafsah, 2003). Salah satu Provinsi penghasil ubi kayu yang cukup besar adalah Provinsi Jawa Barat dengan jumlah produksi pada tahun 2015 adalah 2.000.224 ton. Sentra produksi Ubi Kayu Tersebar di Kabupaten Ciamis, Bogor, Sukabumi, Bandung, Sumedang dan Cianjur. (Badan Pusat Statistik, 2016). Berikut ini adalah data luas panen, produksi dan produktivitas tanaman ubi kayu di Provinsi Jawa Barat.

Tabel 1. Luas Panen, Produksi, dan Produktivitas Ubi Kayu Provinsi Jawa Barat

\begin{tabular}{|c|c|c|c|}
\hline Tahun & $\begin{array}{c}\text { Luas Panen } \\
\text { (Hektar) }\end{array}$ & $\begin{array}{c}\text { Produksi } \\
\text { (Ton) }\end{array}$ & $\begin{array}{c}\text { Produktivitas } \\
\text { (Kwintal/Hektar) }\end{array}$ \\
\hline $\mathbf{2 0 1 1}$ & 103244 & 2058785 & 199.41 \\
\hline $\mathbf{2 0 1 2}$ & 100159 & 2131123 & 212.77 \\
\hline $\mathbf{2 0 1 3}$ & 95505 & 2138532 & 223.92 \\
\hline $\mathbf{2 0 1 4}$ & 93921 & 2250024 & 239.57 \\
\hline $\mathbf{2 0 1 5}$ & 85288 & 2000224 & 234.53 \\
\hline
\end{tabular}

Sumber : Badan Pusat Statistik, 2016

Menurut Kepala Badan Ketahanan

Pangan Kementan Agung Hendriadi, selama ini industri rumahan pangan lokal seperti singkong hingga aneka olahan umbi-umbian kerap kalah bersaing karena hanya sebatas produksi dan saat ini program diversifikasi pangan telah dijalankan di beberapa wilayah meskipun 
belum skala besar. Salah satunya diversifikasi pangan berbasis sorgum di Demak Jawa Tengah dan Larantuka Nusa Tenggara Timur, kemudian sagu di Kehiran Papua, dan jagung di Kupang Timur, serta hanjeli di Sumedang, dan ubi kayu di Cimahi (Julianto, 2017).

Kota Cimahi merupakan salah satu kota yang merupakan tempat diversifikasi pangan berbasis ubi kayu.
Hal ini dilakukan karena rata-rata produksi tanaman ubi kayu pada tahun 2015 merupakan yang tertinggi dibandingkan komoditas padi dan palawija yang berada di Kota cimahi yaitu sebesar 16,35 Ton/Ha. Berikut ini adalah bagan produksi dan rata-rata produksi tanaman padi dan Palawija Kota Cimahi tahun 2015:

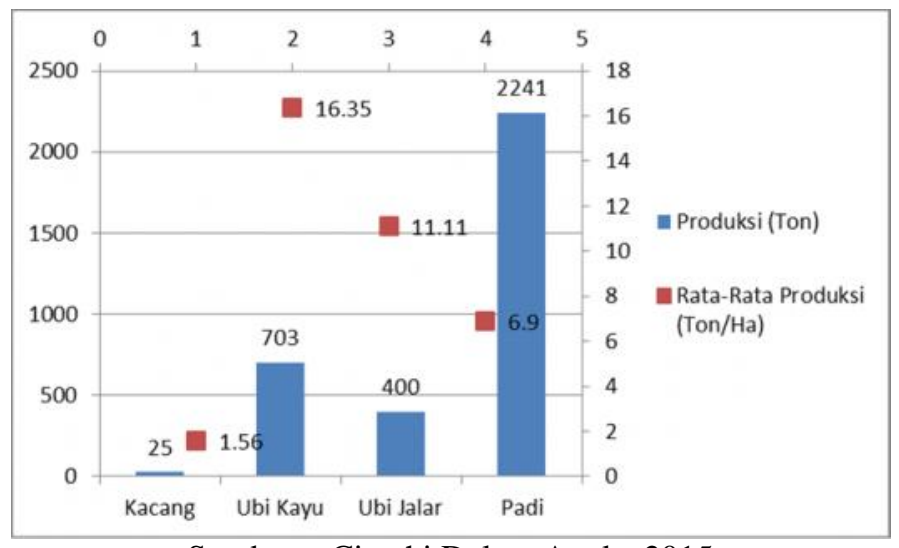

Sumber : Cimahi Dalam Angka 2015

Gambar 1. Produksi dan Rata-rata Produksi Padi Palawija Kota Cimahi 2015

Industri Kecil dan Menengah (IKM) yang ada di Indonesia menjadi salah satu sumber penting bagi perdagangan produk dan jasa, maka menjadi kesempatan untuk para pedagang khususnya IKM (Industri Kecil dan Menengah) untuk terus melakukan perkembangan dalam usaha mereka agar tujuan keberhasilan usaha bisa tercapai. Karena jumlah IKM yang ada di Indonesia menurut Badan Pusat Statistik (BPS) tahun 2016 terdapat lebih dari 57.900.000 unit dan pada tahun 2017 jumlah UMKM lebih dari 59.000.000 unit, dan hal tersebut terus mengalami peningkatan, dan merupakan salah satu penyumbang terbesar bagi devisa negara. (Muhammad Ai, 2016)

Salah satu contoh kota yang sedang mengembangkan sektor industri kecil dan menengah adalah Kota Cimahi. Menurut Dinas Perdagangan, Koperasi, UKM, dan Perindustrian (DISDAGKOPERIN) Kota Cimahi, kontribusi terbesar dalam pembangunan Kota Cimahi didominasi oleh sektor industri pengolahan. Sub 
sektor penyumbang terbanyak adalah sub sektor tekstil, barang kulit dan alas kaki dan kontribusi terbesar kedua adalah sub sektor makanan dan minuman. Hal tersebut berbanding lurus dengan semakin banyaknya pelaku usaha kecil dan mikro yang diharapkan dapat

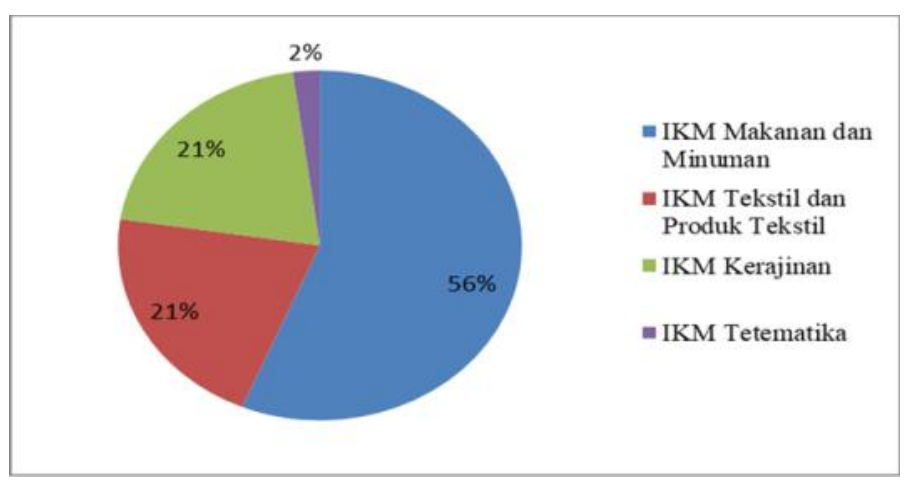

Sumber : Dinas Koperasi, UMKM, Perindustrian, Perdagangan dan Pertanian Kota Cimahi Gambar 2. Bagan Rekapitulasi Data Industri Kecil Menengah Kota Cimahi

Berdasarkan gambar 2, bahwa jumlah pelaku bisnis yang terjun di usaha makanan/minuman mencapai setengah dari seluruh Industri Kecil Menengah (IKM) di Kota Cimahi yaitu sebesar 56\%. Salah satu sub sektor IKM makanan dan minuman yang terbanyak adalah IKM produk aneka keripik yang jumlahnya sekitar 30\% dari seluruh IKM makanan dan minuman Yang terbagi di 3 meningkatkan daya beli masyarakat Cimahi. Dan berikut ini adalah data Industri Kecil Menengah yang ada di Kota Cimahi .

$$
\begin{aligned}
& \text { Minuman } \\
& \text { IKM Tekstil dan } \\
& \text { Produk Tekstil } \\
& \text { IKM Kerajinan } \\
& \text { IKM Tetematika }
\end{aligned}
$$

Tabel 2. Jumlah IKM Makanan dan Minuman dan IKM Produk Aneka Keripik Tahun 2017

\begin{tabular}{|l|r|r|}
\hline \multicolumn{1}{|c|}{ Kecamatan } & \multicolumn{1}{|c|}{$\begin{array}{c}\text { Jumlah IKM } \\
\text { Makanan dan } \\
\text { Minuman }\end{array}$} & $\begin{array}{c}\text { Jumlah IKM Produk Aneka } \\
\text { Keripik }\end{array}$ \\
\hline Cimahi Selatan & 139 & 33 \\
\hline Cimahi Tengah & 210 & 70 \\
\hline Cimahi Utara & 147 & 46 \\
\hline Total & 496 & 149 \\
\hline
\end{tabular}

Sumber: Data diolah, 2018 
Berdasarkan data terbaru dari

Dinas Koperasi, UMKM dan Perindustrian Perdagangan Kota Cimahi tahun 2016, terdapat sebanyak 496 Industri Kecil Menengah (IKM) yang ada di Kota Cimahi. Diantara IKM tersebut terdapat Industri makanan ringan, kue kering khas Cimahi, aneka snack, dan keripik pedas. Untuk IKM produk anek keripik terdapat 70 IKM di Cimahi Tengah dan sebanyak 44 IKM berada di Kelurahan Setiamanah dan untuk Kampung Pojok merupakan pusat produksi keripik singkong di Kota Cimahi. Hal tersebut membuat Pemerintah Kota Cimahi meresmikan daerah Pojok yang bertempat di Kelurahan Setiamanah sebagai daerah Sentra Produksi Keripik Singkong Pedas Kota CImahi.

Menurut hasil wawancara awal yang dilakukan kepada Kepala Dinas Perdagangan, Koperasi, UKM, dan Perindustrian (DISDAGKOPERIN) Kota Cimahi, Usaha Mikro, Kecil dan Menengah (UMKM) bahwa makanan dan minuman yang sedang berkembang pesat adalah UMKM keripik Singkong. UMKM tersebut terdapat di Kelurahan Setiamanah Kecamatan Cimahi Tengah
Kota Cimahi. Para pelaku UMKM tergabung di Paguyuban Pengusaha Keripik Pedas Pojok Cimahi yang diketuai oleh Bapak Yugo. Alasan mengapa mereka membuka usaha keripik singkong adalah karena bahan baku yang mudah didapat, mudah diolah dan harganya murah.

Kapasitas produksi salah satu pengrajin di Sentra Produksi Keripik Singkong Pedas Cimahi menghasilkan 45 ton per minggu dengan nilai omset sekitar Rp 60 juta/minggu dan untuk perbulannya omset dapat mencapai Rp300 juta/bulan bahkan pernah menembus 1 milyar/bulan pada waktu lebaran. Dan tujuan pemasaran mereka rata-rata adalah sekolah-sekolah, grosir, pasar dan anak-anak muda. Wilayah penjualan sendiri telah mencangkup wilayah kota Cimahi, Bandung, Jakarta dan daerah-daerah lainnya membuat penghasilan warga didaerah industri ini makin bertambah. Untuk penjualannya sendiri saat ini sedang stabil. Berikut ini adalah data penjualan keripik singkong tahun 2015-2016 


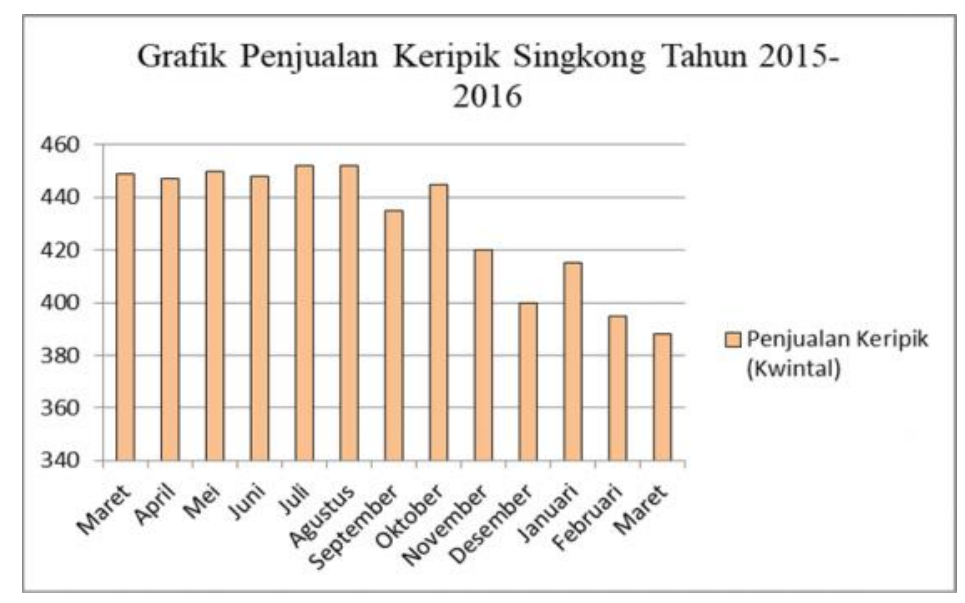

Gambar 1. Grafik Penjualan Keripik Singkong di Sentra Produksi Keripik Singkong Pedas Cimahi Tahun 2015-2016

Sumber: Bendahara Sentra Industri Keripik Singkong Pedas Cimahi (http://elib.unikom.ac.id)

Dengan adanya kegiatan industri yang mengubah bentuk primer menjadi produk baru yang lebih tinggi nilai ekonomisnya setelah melalui proses pengolahan, maka akan dapat memberikan nilai tambah karena dikeluarkan biaya-biaya sehingga terbentuk harga baru yang lebih tinggi dan keuntungan yang lebih besar bila dibandingkan tanpa melalui proses pengolahan. Dengan melakukan analisis usaha dan nilai pelaku usaha keripik singkong dapat mengetahui seberapa besar nilai tambah yang mereka hasilkan dan berapa biaya dan keuntungan yang dikeluarkan per-sekali produksi secara detail, apakah usaha yang mereka jalankan sudah efisien atau tidak dan hasil tersebut dapat menjadi acuan untuk perencanaan kedepannya.
Berdasarkan uraian tersebut, maka masalah yang ada di Sentra Produksi Keripik Singkong Pedas Cimahi adalah sebagai berikut: 1) Berapa nilai tambah yang diperoleh dari pengolahan ubi kayu menjadi keripik singkong.

\section{METODE PENELITIAN}

Desain yang digunakan dalam penelitian ini adalah desain kualitatif dengan pendekatan kuantitatif. Desain kualitatif dipilih karena dalam penelitian ini dibutuhkan pendekatan individu yang mendalam dan terperinci terhadap setiap informan, supaya hasil yang didapatkan dapat valid atau benar. Metode yang digunakan dalam penelitian ini adalah studi kasus. Teknik studi kasus yang digunakan adalah survey deskriptif.

Sumber data yang digunakan adalah Data primer yang meliputi ata 
perusahaan, permodalan, nilai peralatan dan mesin, tempat usaha dan lain-lain, dan Data sekunder yang diperoleh dari lembaga dan unsur-unsur yang berhubungan dengan penelitian. Teknik Pengumpulan yang digunakan adalah penelitian lapangan, studi kepustakaan dan dokumentasi.
Adapun rancangan analisis data yang digunakan adalah Analisis Nilai Tambah dengan Menggunakan metode hayami. Menurut Hayami et al. (1987), nilai tambah (value added) adalah pertambahan nilai suatu komoditas karena mengalami proses pengolahan, pengangkutan ataupun penyimpanan dalam suatu produksi.

Tabel 3. Tabel Nilai Tambah Metode Hayami

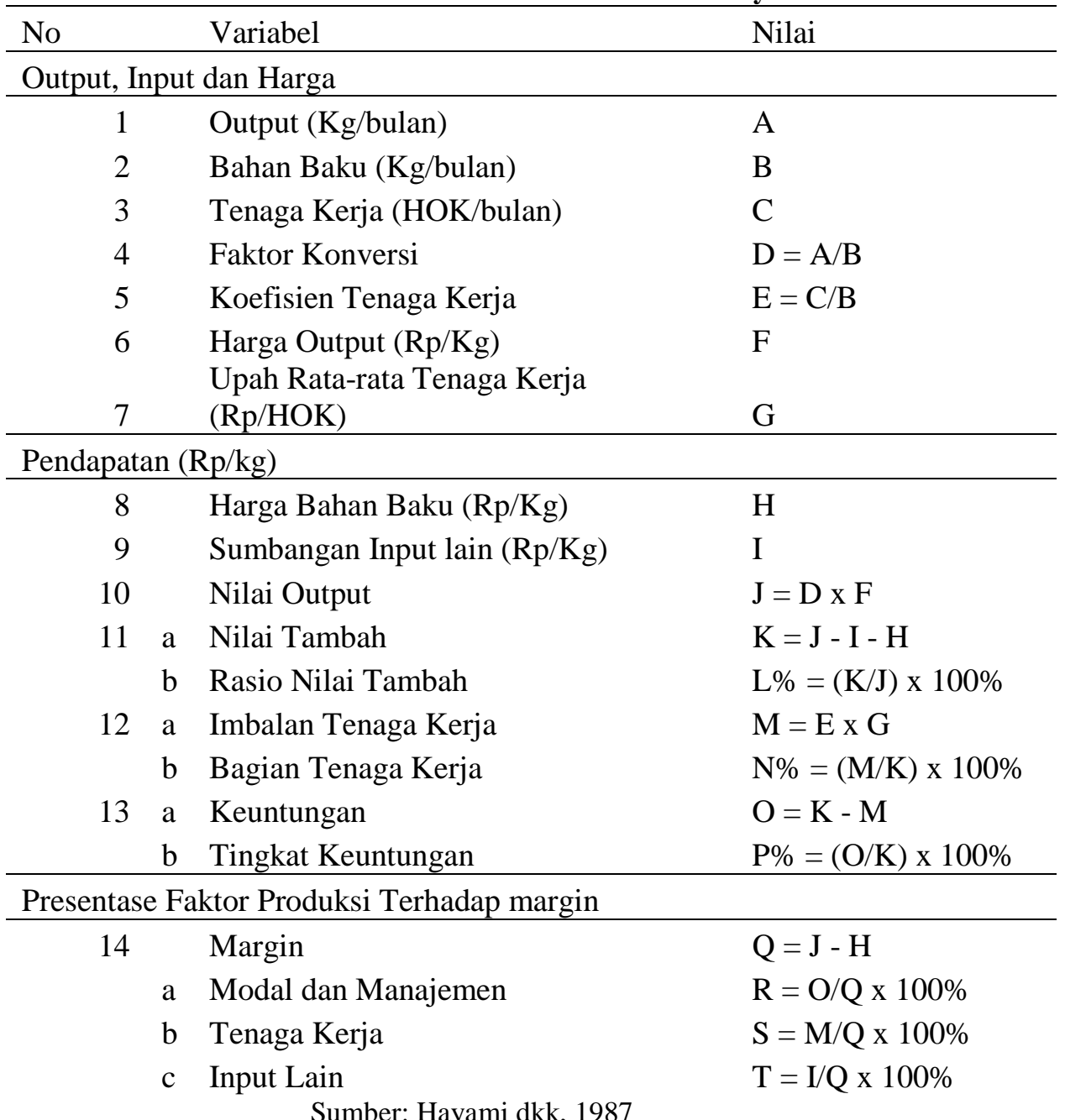

\section{HASIL DAN PEMBAHASAN}

\section{Analisis Nilai Tambah}

Nilai tambah merupakan pertambahan nilai suatu komoditas karena telah mengalami proses pengolahan, pengangkutan, atau penyimpanan dalam suatu proses produksi. Kegiatan pengolahan keripik 
singkong akan memberikan nilai tambah dan memberikan keuntungan yang dapat dinikmati para pemilik faktor produksi, khususnya pengusaha keripik singkong, dan juga para konsumen yang menikmatinya.

\section{Dalam Agroindustri keripik} singkong ini dapat menambah nilai dari produk yang digunakan, apabila dilihat dari kegunaan tempat (place utility) setelah diolah menjadi keripik singkong produk ini dapat dipasarkan tidak hanya di daerah Cimahi saja akan tetapi sudah bisa dipasarkan ke kota-kota lain seperti Jakarta, Bogor, Depok, Tangerang, dan Bekasi sehingga produk ini bisa lebih dikenal lagi. Kegunaan waktu (time utility) dari produk ini adalah produk menjadi lebih bertahan lama setelah diproses menjadi keripik singkong, karena pada dasarnya produk-produk hasil pertanian tidak dapat bertahan lama karena mudah busuk. Selanjutnya yaitu kegunaan bentuk (form utility) setelah ubi kayu ini diolah menjadi keripik singkong dengan bentuk yang menarik dan rasa yang lezat membuat banyak konsumen tertarik untuk membeli produk tersebut.

$$
\text { Menurut (Hayami et al,1987 }
$$
dalam ACIAR, 2012), Nilai tambah (value added) adalah pertambahan nilai suatu komoditas karena mengalami proses pengolahan, pengangkutan ataupun penyimpanan dalam suatu produksi. Berdasarkan pengertian tersebut, perubahan nilai bahan baku yang telah mengalami perlakuan pengolahan besar nilainya dapat diperkirakan. Dengan demikian, atas dasar nilai tambah yang diperoleh, marjin dapat dihitung dan selanjutnya imbalan bagi faktor produksi dapat diketahui.

Berikut ini adalah analisis biaya per $1 \mathrm{~kg}$ keripik singkong yang dilakukan pada Sentra Produksi Keripik Singkong Pedas Cimahi:

Tabel 4. Rata-rata Nilai Tambah Keripik Singkong Kemasan Sachet dan Kemasan Curah

\begin{tabular}{|c|c|c|c|c|c|}
\hline \multirow[b]{2}{*}{ Proses Produksi } & \multicolumn{2}{|c|}{ Biaya } & \multirow[b]{2}{*}{$\begin{array}{c}\text { Harga Jual } \\
\text { per unit } \\
\text { (Rp/kg) }\end{array}$} & \multirow[b]{2}{*}{$\begin{array}{c}\text { Margin } \\
\text { Profit (Rp) }\end{array}$} & \multirow{2}{*}{$\begin{array}{c}\text { Nilai } \\
\text { Tambah Ubi } \\
\text { Kayu } \\
\text { (Total) (Rp) }\end{array}$} \\
\hline & $\begin{array}{l}\text { Biaya Per } \\
\text { Unit } \\
(\mathrm{Rp} / \mathrm{kg}) \\
\end{array}$ & $\begin{array}{c}\text { Total Biaya } \\
\text { Per Unit } \\
(\mathrm{Rp} / \mathrm{kg}\end{array}$ & & & \\
\hline Penyiapan ubi kayu & $2.463,30$ & $2.463,30$ & - & - & - \\
\hline Pengupasan Kulit Luar & 140,36 & $2.603,36$ & - & - & - \\
\hline Pemotongan/Perajangan & 86,24 & $2.689,60$ & - & - & - \\
\hline Pencucian & 26,55 & $2.716,15$ & - & - & - \\
\hline Penggorengan & $1.917,96$ & $4.834,11$ & - & - & - \\
\hline Pemberian bumbu & $14.227,96$ & $18.862,07$ & - & - & - \\
\hline Pengemasan Sachet & $1.979,91$ & $11.033,61$ & $35.000,00$ & $23.966,39$ & $32.536,70$ \\
\hline Pengemasan Curah & $5.425,54$ & $15.233,61$ & $28.000,00$ & $12.766,39$ & $25.536,70$ \\
\hline Total & & $26.267,82$ & $31.500,00$ & $5.232,18$ & $29.036,70$ \\
\hline
\end{tabular}


Dari semua biaya per proses didapatkan bahwa total Biaya per $1 \mathrm{~kg}$ keripik singkong dari semua proses produksi adalah Rp11.033,61 untuk pengemasan keripik singkong ukuran kecil dan Rp15.233,61 untuk kemasan curah. Untuk lebih detailnya dapat dilihat pada tabel 4 .

Pada tabel 4 , rata-rata total biaya per unit pengemasan sachet dan curah dihitung dari pertambahan seluruh total biaya sampai dengan proses produksi pemberian bumbu, dengan perbandingan produksi keripik singkong untuk kemasan sachet $48 \%$ dan kemasan curah 52\%, hal ini dilakukan karena rata-rata produksi yang dilakukan pengusaha keripik singkong di Sentra Produksi Keripik Singkong Pedas Cimahi seperti itu. Sehingga dari rata-rata total biaya sampai dengan proses pemberian bumbu untuk kemasan sachet adalah Rp9.053,79 dan untuk kemasan curah sebesar Rp9.808,28. Jadi rata-rata total biaya per unit yang didapatkan untuk kemasan sachet adalah Rp11.033,61, kemasan curah adalah Rp15.233,61 dan rata-rata total biaya per unit seluruh proses produksinya adalah Rp26.267,82 .

Menurut (ACIAR, 2012), margin profit dapat didefinisikan sebagai selisih antara nilai produk dengan nilai biaya bahan baku dan input lainnya. Sehingga nilai tambah yang dihasilkan dari keripik singkong kemasan sachet adalah Rp23.966,39 didapatkan dari harga jual keripik singkong kemasan sachet sebesar Rp35.000,00 dikurangi oleh seluruh ratarata total biaya per unit untuk kemasan sachet sebesar Rp11.033,61. Untuk kemasan curah nilai tambah yang didapatkan adalah Rp12.766,39 dengan harga jual Rp28.000,00 dan rata-rata total biaya per unit nya adalah Rp15.233,61. Dan untuk harga jual per unit total seluruh produksi dirata-ratakan terlebih dahulu dan didapatkan harga Rp31.500,00, nilai tambah yang didapatkan adalah Rp5.232,18.

Menurut (ACIAR, 2012), nilai tambah ubi kayu (total) adalah selisih antara nilai produk dengan harga bahan bakunya saja. Jadi rata-rata nilai tambah ubi kayu (total) yang didapatkan untuk keripik singkong kemasan sachet adalah Rp32.536,70, untuk kemasan curah adalah Rp25.536,70 dan untuk rata-rata total seluruh produksinya sebesar Rp29.036,70

Dan berikut ini adalah analisis nilai tambah rata-rata para pengusaha keripik singkong Sentra Produksi Keripik Singkong Pedas Cimahi, dalam penelitian ini dihitung untuk mengetahui 
pertambahan nilai ubi kayu menjadi keripik singkong dengan menggunakan dasar perhitungan input per kilogram bahan baku selama satu kali proses produksi. Untuk menghitung nilai tambah keripik singkong tersebut menggunakan analisis nilai tambah Metode Hayami seperti pada tabel 5 .

Tabel 5. Rata-rata Nilai Tambah Agroindustri Keripik Singkong per Proses Produksi

\begin{tabular}{|c|c|c|}
\hline No & Variasi Nilai Tambah & Nilai \\
\hline & Input, Output, dan Harga & \\
\hline 1 & Output (kg/proses produksi) & 189,70 \\
\hline 2 & Jumlah bahan baku (kg/proses produksi) & 314,00 \\
\hline 3 & Tenaga Kerja (HOK/proses produksi) & 13,90 \\
\hline 4 & Faktor Konversi (1/2) & 0,63 \\
\hline 5 & Koefisien Tenaga Kerja (3/2) & 0,05 \\
\hline 6 & Harga output $(\mathrm{Rp} / \mathrm{kg})$ & 31500,00 \\
\hline \multirow[t]{2}{*}{7} & Upah rata-rata tenaga Kerja (Rp/HOK) & 20057,68 \\
\hline & Pendapatan dan Keuntungan & \\
\hline 8 & Harga Bahan Baku (Rp/Kg) & 1530,00 \\
\hline 9 & Sumbangan Input lain $(\mathrm{Rp} / \mathrm{kg})$ & 13004,07 \\
\hline 10 & Nilai Output (Rp/kg/produksi) $(4 * 6)$ & 19766,25 \\
\hline \multirow[t]{2}{*}{11} & a) Nilai Tambah (10-8-9) & 5232,18 \\
\hline & b) Rasio Nilai Tambah (\%) (11a/10)\% & 23,76 \\
\hline \multirow[t]{2}{*}{12} & a) Pendapatan Tenaga Kerja ( $\mathrm{Rp} / \mathrm{kg} / \mathrm{prod})\left(5^{*} 7\right)$ & 977,92 \\
\hline & b) Bagian Tenaga Kerja (\%) (12a/11a)\% & 20,45 \\
\hline \multirow[t]{3}{*}{13} & a) Keuntungan (Rp/kg/produksi) (11a-12a) & 3746,50 \\
\hline & b) Tingkat Keuntungan (\%) (13a/10)\% & 18,95 \\
\hline & Balas jasa untuk faktor produksi & \\
\hline \multirow[t]{4}{*}{14} & Marjin & 17747,76 \\
\hline & a) Imbalan tenaga kerja (\%) $(12 \mathrm{a} / 14) \%$ & 5,39 \\
\hline & b) Sumbangan Input lain (\%) $(9 / 14) \%$ & 76,38 \\
\hline & c) Keuntungan $(\%)(13 \mathrm{a} / 14) \%$ & 21,05 \\
\hline
\end{tabular}

Berdasarkan tabel 5, dapat dilihat bahwa mengolah keripik singkong dalam satu kali proses produksi rata-rata diperlukan bahan baku ubi kayu sebanyak $314 \mathrm{~kg}$ per proses produksi yang menghasilkan keripik singkong sebanyak $189,7 \mathrm{~kg}$ per proses produksi. Harga ratarata bahan baku ubi kayu adalah Rp1530,00 per kilogramnya. Banyaknya keripik singkong yang dihasilkan dan input bahan baku di dapat faktor konversi sebesar 0,63 yang menunjukkan bahwa setiap satu kilogram ubi kayu yang diolah rata-rata menghasilkan keripik singkong sebanyak 0,63 kilogram. Besar kecilnya faktor konversi dipengaruhi kualitas bahan baku. Semakin besar faktor 
konversinya maka semakin produktif pengolahannya.

Proses pengolahan bahan baku dalam satu kali proses produksi diperlukan 13,9 HOK per proses produksi dengan upah sebesar Rp20.057,68 per HOK. Pada agroindustri pengolahan keripik singkong di Sentra Produksi Keripik Singkong Pedas Cimahi para pengusaha banyak menggunakan tenaga kerja dari luar keluarga. Koefisien tenaga kerja diperoleh dengan membagi jumlah tenaga kerja dengan jumlah bahan baku yang digunakan dalam satu kali proses produksi yaitu 0,05. Nilai koefisien tenaga kerja adalah banyaknya tenaga kerja langsung yang diperlukan untuk mengolah satu kilogram bahan baku atau jumlah tenaga kerja yang diserap dalam proses pengolahan ubi kayu menjadi keripik singkong.

Pengolahan ubi kayu menjadi keripik singkong membutuhkan sumbangan input lain rata-rata Rp13.004,07. Sumbangan input lain adalah biaya penunjang dan bahan bakar per kilogram bahan baku. Rata-rata biaya bahan penunjang dan bahan bakar adalah Rp3.508.120,00 dari 314 kg ubi kayu. Jadi dari satu kilogram keripik singkong dibutuhkan bahan penunjang dan bahan bakar dengan biaya rata-rata
Rp13.004,07, sehingga rata-rata sumbangan input lainnya adalah Rp13.004,07.

Nilai output menunjukkan nilai produk yang dihasilkan dari pengolahan satu kilogram bahan baku yaitu Rp19.766,25 yang merupakan hasil perkaliaan antara faktor konversi dengan harga output. Harga keripik singkong per kilogramnya adalah Rp31.500,00. Penetapan harga keripik singkong dari setiap pengusaha sama karena ada kesepakatan diantara pengusaha, supaya tidak terjadi persaingan dalam penentuan harga.

Rata-rata nilai tambah yang diperoleh dari pengolahan satu kilogram bahan baku jadi sebesar Rp5.232,18 per kilogram artinya setiap satu kilogram input (ubi kayu) akan menghasilkan output (keripik singkong) sebesar Rp5.232,18 dan rasio nilai tambah terhadap nilai output rata-rata sebesar $23,76 \%$ per proses produksi. Menurut Hubbeis (1997), rasio nilai tambah ini termasuk dalam nilai tambah sedang karena berada diantara $15-40 \%$.

Pendapatan tenaga kerja rata-rata untuk mengolah bahan baku keripik singkong adalah Rp977,92 per kilogram bahan baku. Besarnya persentase rata-rata bagian pendapatan tenaga kerja terhadap 
nilai tambah adalah $20,45 \%$. Pendapatan tenaga kerja merupakan upah yang diterima tenaga kerja langsung untuk mengolah satu kilogram bahan baku. Besarnya pendapatan tergantung dari bahan baku yang diolah dan tingkat upah yang ditetapkan oleh pengusaha. Dilihat dari persentase rata-rata bagian pendapatan tenaga kerja maka pendapatan dipengaruhi oleh koefisien tenaga kerja, semakin besar nilai koefisien maka akan semakin besar imbalan yang diterima pekerja.

Keuntungan diperoleh dengan mengurangkan pendapatan tenaga kerja dari nilai tambah. Keuntungan rata-rata diperolah pengusaha dari pengolahan satu kilogram ubi kayu menjadi keripik singkong adalah Rp3.746,50 dengan persentase tingkat keuntungan 18,95\%. Keuntungan dapat diartikan sebagai nilai tambah bersih yang diterima pengusaha dalam satu kali proses produksi per kilogram bahan baku yang diolah karena sudah tidak mengandung imbalan atau pendapatan tenaga kerja.

Marjin merupakan selisih nilai output dengan harga bahan baku yang merupakan total balas jasa terhadap pemilik faktor produksi. Rata-rata marjin yang didapatkan adalah Rp17.747,76 per kilogram bahan baku, yang selanjutnya didistribusikan untuk pendapatan tenaga kerja sebesar 5,39 \% atau Rp977,92 dan sumbangan bahan penunjang $76,38 \%$ atau Rp13.004,07 serta keuntungan usaha $21,05 \%$ atau Rp3.746,50.

\section{KESIMPULAN DAN SARAN}

\subsection{Kesimpulan}

Besarnya rata-rata nilai tambah untuk keripik singkong kemasan sachet adalah Rp23.966,39 dan untuk pengemasan curah adalah Rp12.766,39. Untuk rata-rata total nilai tambah usaha pengolahan ubi kayu menjadi keripik singkong yang diperoleh tiap pengrajin bervariasi antara Rp3.050,00 Rp6.492,22 per kilogram bahan baku tiap satu kali proses produksinya. Rata-rata nilai tambah diterima oleh pengusaha keripik singkong sebesar Rp5232,18 per kilogram bahan baku atau rasio nilai tambah terhadap nilai output rata-rata sebesar $23,76 \%$ per proses produksi. Rasio nilai tambah ini termasuk dalam nilai tambah tersebut termasuk dalam kategori sedang karena berada diantara $15-40 \%$.

\subsection{Saran}

1. Untuk pengusaha sebaiknya melakukan pembukuan yang baik mengenai produksi keripik singkong 
setiap kali produksi. Gunanya agar pengusaha dapat mengontrol jumlah produksinya serta mengetahui kekurangan serta kelemahan apa saja yang ada pada produksi keripik singkong

2. Dalam upaya yang mengarah pada perbaikan kualitas dan kuantitas keripik singkong yang dihasilkan, perlu adanya kesadaran dari pengusaha akan kebersihan di sekitar tempar produksi, alat-alat yang digunakan, dan kebersihan pengrajin sendiri.

3. Perlu berjalannya koperasi paguyuban karena dengan berjalannya koperasi akan sangat membantu para pengusaha untuk mendapatkan modal dan bantuan dari pemerintah. Selain itu akan memudahkan juga dalam proses pemasaran dan pengadaan bahan baku, karena dengan berjalannya koperasi pembelian bahan baku dapat terpusat dan pemasaran hasil produk dapat terbantu.

4. Perlu dilakukan berbagai upaya untuk mempromosikan keripik singkong ke masyarakat luas sehingga dapat meningkatkan pembeli potensial produk ini. Upaya yang dapat dilakukan, di antaranya mengikuti berbagai pameran, memasang iklan di media cetak maupun elektronik, brosur, dan melakukan penjualan pribadi (personal selling) ke konsumen.

5. Melihat nilai tambah yang dihasilkan, agroindustri keripik singkong ini berpotensi untuk dikembangkan, perlunya perhatian dan pembinaan dari pemerintah maupun instansi terkait yang mencakup aspek manajemen, teknologi, permodalan, dan pemasaran

\section{DAFTAR PUSTAKA}

Australian Centre for International Agricultural Research (ACIAR). 2012. Making Value Chain Work Better for the Poor: A Toolbook for Practitioners of Value Chain Analysis. Canbera (Australia)

Badan Pusat Statistik (BPS) Kota Cimahi. 2016. Statistik Daerah Kota Cimahi 2015. <http://cimahikota.bps.go.id $>$. Diakses pada 19 April 2017

Hafsah MJ. 2003. Bisnis Ubi Kayu Indonesia. Jakarta: Pustaka Sinar Harapan.

Hayami, Y. et al. 1987. Agricultural marketing and processing in upland Java. A perspective from a Sunda village. CGPRT Centre. Bogor.

Ismini. 2010. Analisis Nilai Tambah dan Strategi Pemasaran Keripik Singkong di Perusahaan "Mickey Mouse" di Malang. Agrika, Vol 4 No 
<http://widyagama.ac.id/pertanian/

wp-

content/uploads/2012/01/6Ismini-

Analisis-Nilai-Tambah.pdf $>$.

Diakses tanggal 27 Mei 2017.

Julianto, Pramida Arhando. 2017.

Program Diversifikasi Pangan

Masih Banyak Kendala.

<https://ekonomi.kompas.com/read /2017/10/25/080000126/program-

diversifikasi-pangan-masih-banyak- kendala $>$. Diakses pada Tanggal 30 Maret 2018.

Muhammad Ai. 2016. Perkembangan UMKM (Usaha mikro kecil dan menengah) di Indonesia. Cano Ekonomos, 6(1), pp.51-58. 